\section{Chrolactomycin, a Novel Antitumor Antibiotic Produced by Streptomyces sp.}

\author{
Ryuichiro Nakai, Shingo Kakita ${ }^{\dagger}$, AKIRA Asal, \\ Shigeru Chiba $^{\dagger \dagger}$, Shiro Akinaga, Tamio Mizukami \\ and YOSHINORI YAMASHITA* \\ Pharmaceutical Research Institute, \\ Kyowa Hakko Kogyo Co., Ltd., \\ 1188 Shimotogari, Nagaizumi-cho, Sunto-gun, \\ Shizuoka 411-8731, Japan \\ †Tokyo Research Laboratories, Kyowa Hakko Kogyo Co., Ltd., \\ 3-6-6 Asahimachi, Machida-shi, Tokyo 194-8533, Japan \\ ${ }^{\dagger+}$ Technical Research Laboratories, \\ Kyowa Hakko Kogyo Co., Ltd., \\ 1-1 Kyowa-cho, Houfu-shi, Yamaguchi 747-8522, Japan
}

(Received for publication May 11, 2001)

In the course of our screening for antitumor antibiotics, a novel compound, chrolactomycin, was isolated from Streptomyces sp. 569N-3. Chrolactomycin exhibited antimicrobial activity and antiproliferative activity against human tumor cell lines. In this paper, we describe the fermentation, isolation, physico-chemical properties, structure elucidation and biological activities of chrolactomycin.

A loopful of the cells from a mature slant of strain $569 \mathrm{~N}-$ 3 was inoculated into each of two 300-ml Erlenmeyer flasks containing $30 \mathrm{ml}$ of the seed medium composed of glucose $1 \%$, soluble starch $1 \%$, Bacto tryptone $0.5 \%$, beef extract $0.3 \%$, yeast extract $0.5 \%$ and $\mathrm{Mg}_{3}\left(\mathrm{PO}_{4}\right)_{2} \cdot 8 \mathrm{H}_{2} \mathrm{O} 0.05 \%$ in deionized water ( $\mathrm{pH} 7.2$ prior to sterilization). The inoculated flask content was incubated on a rotary shaker at $28^{\circ} \mathrm{C}$ for 3 days. $7.5 \mathrm{ml}$ of the seed culture was added to a 1-liter Erlenmeyer flask containing $150 \mathrm{ml}$ of the same medium. Following 2 days of incubation at $28^{\circ} \mathrm{C}$, one hundred fifty $\mathrm{ml}$ of the second stage seed culture was transferred into a 5-liter jar fermenter containing 3 liters of the same medium. After incubation on a fermenter at $28^{\circ} \mathrm{C}$ for 1 day, nine hundred $\mathrm{ml}$ of the third stage seed culture was transferred into a 30-liter jar fermenter containing 18 liters of a fermentation medium composed of sucrose $5 \%$, dry yeast $1.5 \%, \mathrm{KH}_{2} \mathrm{PO}_{4} 0.05 \%, \mathrm{Mg}_{2} \mathrm{SO}_{4} \cdot 7 \mathrm{H}_{2} \mathrm{O} 0.05 \%$ and $\mathrm{Mg}_{3}\left(\mathrm{PO}_{4}\right)_{2} \cdot 8 \mathrm{H}_{2} \mathrm{O} 0.05 \%$ in deionized water $(\mathrm{pH} 7.0$ prior to sterilization). The fermentation was carried out at $28^{\circ} \mathrm{C}$ for 8 days with agitation of $150 \mathrm{rpm}$ and aeration of 18 liters per minute.

The culture broth (13.8 liters) was divided into culture filtrate and mycelial cake by a centrifugal filter. The mycelial cake was extracted with $\mathrm{MeOH}$. After filtration,

Table 1. Physico-chemical properties of chrolactomycin.

\begin{tabular}{ll}
\hline Appearance & White powder \\
Melting point & $130 \cdot 131^{\circ} \mathrm{C}$ \\
{$[\alpha]_{D}^{28.5}(\mathrm{c} 0.45, \mathrm{MeOH})$} & $-7.75^{\circ}$ \\
Molecular formula & $\mathrm{C}_{24} \mathrm{H}_{32} \mathrm{O}_{7}$ \\
FAB-MS $(\mathrm{m} / \mathrm{z})$ & $433[\mathrm{M}+\mathrm{H}]^{+}, 431[\mathrm{M} \cdot \mathrm{H}]$ \\
HRFAB-MS $(\mathrm{m} / \mathrm{z})$ & \\
$\quad$ Found & $431.2087[\mathrm{M} \cdot \mathrm{H}]$ \\
$\quad$ Calcd. & $431.2069\left(\mathrm{for} \mathrm{C}_{24} \mathrm{H}_{31} \mathrm{O}_{7}\right)$ \\
UV $\lambda_{\max } \mathrm{nm}(\varepsilon)(\mathrm{MeOH})$ & $209.8(4738)$ \\
IR $v_{\max }(\mathrm{KBr}) \mathrm{cm}^{-1}$ & $3800-2400,3410,2954,2929$, \\
& $2866,1793,1712,1689,1641$, \\
& $1626,1458,1255,1186,1178$, \\
& $1113,1074,966$ \\
TLC (Rf value $\left.{ }^{\mathrm{a}}\right)$ & 0.41 \\
Solubility & \\
$\quad$ Soluble & $\mathrm{MeOH}, \mathrm{Me} 2 \mathrm{CO}, \mathrm{AcOEt}, \mathrm{CHCl}_{3}, \mathrm{DMSO}$ \\
$\quad$ Insoluble & $\mathrm{Hexane}$ \\
\hline
\end{tabular}

${ }^{a}$ Silica gel TLC (Kieselgel $60 \mathrm{~F}_{254}$, Merck), solvent: $\mathrm{CHCl}_{3}-\mathrm{MeOH}(19: 1)$.

* Corresponding author: yyamashita@kyowa.co.jp 
the $\mathrm{MeOH}$ extract was combined with the culture filtrate and the mixture was applied to a column of Diaion HP-20 (2 liters, Mitsubishi Chemical Industries). The column was washed with deionized water-MeOH $(2: 8)$ and eluted with $\mathrm{MeOH}$ ( 6 liters). The eluate was concentrated and extracted with $\mathrm{CHCl}_{3}$ at $\mathrm{pH}$ 3.0. The extract was concentrated in vacuo to yield a brown oil. The oil was applied to a column of silica gel Wakogel C-200 (Wako Pure Chemical Industries). The column was washed with $\mathrm{CHCl}_{3}-\mathrm{MeOH}$ $(800: 1)$ and the active substance was eluted with $\mathrm{CHCl}_{3}$ $\mathrm{MeOH}(200: 1)$. The eluate was concentrated in vacuo and then applied to a column of Diaion HP-20SS. The column was eluted with deionized water-acetonitrile $(1: 1)$ followed by a gradient of deionized water-acetonitrile $(45: 55 \sim 30: 70)$. This eluate was concentrated in vacuo and then applied to a column of silica gel LiChroprep Si 60 (Merck). The column was washed with hexane-acetone $(86: 14)$ followed by hexane - acetone $(85: 15 \sim 78: 22)$ to elute the active fractions which were combined and concentrated to yield $325 \mathrm{mg}$ of chrolactomycin as a white powder.

The physico-chemical properties of chrolactomycin are summarized in Table 1 . The molecular formula of chrolactomyin was found to be $\mathrm{C}_{24} \mathrm{H}_{32} \mathrm{O}_{7}$ by $\mathrm{HRFAB}$ mass measurement. The ${ }^{1} \mathrm{H}$ and ${ }^{13} \mathrm{C}$ NMR data of chrolactomycin are shown in Table 2. The ${ }^{13} \mathrm{C}$ NMR data and a DEPT experiment revealed the presence of four methyl carbons, six methylene carbons, seven methine carbons and seven quaternary carbons. The molecular formula agreed well with these data requiring one $\mathrm{H}_{2} \mathrm{O}$-exchangeable proton. ${ }^{1} \mathrm{H}-{ }^{1} \mathrm{H}$ COSY, HSQC (Hetronuclear Single Quantum Coherence spectroscopy) and HMBC experiments revealed the partial structure of chrolactomycin as shown in Fig. 1. There was no cross peak from the carbonyl carbon $\left(d_{c}\right.$ 168.88) in the HMBC experiment. However, of the remaining atoms, $\mathrm{CO}_{2}$, the chemical shifts of $\mathrm{C}-13\left(\mathrm{~d}_{\mathrm{c}}\right.$

Table 2. ${ }^{1} \mathrm{H}$ and ${ }^{13} \mathrm{C}$ NMR data of chrolactomycin in $\mathrm{CDCl}_{3}$.

\begin{tabular}{|c|c|c|}
\hline Position & ${ }^{1} \mathrm{H}$ chemical shift & ${ }^{13} \mathrm{C}$ chemical shift \\
\hline 1 & $2.34(1 \mathrm{H}, \mathrm{m})$ & $42.67(\mathrm{~d})$ \\
\hline \multirow[t]{2}{*}{2} & $1.25(1 \mathrm{H}, \mathrm{m})$ & $32.11(\mathrm{t})$ \\
\hline & $1.61(1 \mathrm{H}, \mathrm{m})$ & \\
\hline 3 & $1.62(2 \mathrm{H}, \mathrm{m})$ & $23.77(\mathrm{t})$ \\
\hline \multirow[t]{2}{*}{4} & $1.03(1 \mathrm{H}, \mathrm{m})$ & $37.58(\mathrm{t})$ \\
\hline & $1.21(1 \mathrm{H}, \mathrm{m})$ & \\
\hline 5 & $1.79(1 \mathrm{H}, \mathrm{m})$ & $30.35(d)$ \\
\hline \multirow[t]{2}{*}{6} & $0.94(1 \mathrm{H}, \mathrm{m})$ & $45.06(t)$ \\
\hline & $1.55(1 \mathrm{H}, \mathrm{dd}, \mathrm{J}=9.6,14.3 \mathrm{~Hz})$ & \\
\hline 7 & $1.95(1 \mathrm{H}, \mathrm{m})$ & $34.50(\mathrm{~d})$ \\
\hline 8 & $4.26(1 \mathrm{H}$, br. $\mathrm{d}, \mathrm{J}=9.8 \mathrm{~Hz})$ & $82.09(\mathrm{~d})$ \\
\hline 9 & & $143.71(\mathrm{~s})$ \\
\hline 10 & & $190.05(\mathrm{~s})$ \\
\hline 11 & & $78.55(\mathrm{~s})$ \\
\hline 12 & $4.53(1 \mathrm{H}, \mathrm{s})$ & $83,96(d)$ \\
\hline 13 & & $83.36(\mathrm{~s})$ \\
\hline \multirow[t]{2}{*}{14} & $1.34(1 \mathrm{H}, \mathrm{ddd}, \mathrm{J}=2.0,6.7,14.9 \mathrm{~Hz})$ & $34.34(\mathrm{t})$ \\
\hline & $1.76(1 \mathrm{H}, \mathrm{dd}, \mathrm{J}=10.5,14.9 \mathrm{~Hz})$ & \\
\hline 15 & $2.71(1 \mathrm{H}, \mathrm{m})$ & $27.19(\mathrm{~d})$ \\
\hline 16 & & $132.90(\mathrm{~s})$ \\
\hline 17 & $6.83(1 \mathrm{H}, \mathrm{dd}, \mathrm{J}=1.8,6.0 \mathrm{~Hz})$ & $140.88(d)$ \\
\hline 18 & & $171.04(\mathrm{~s})$ \\
\hline 19 & $1.12(3 \mathrm{H}, \mathrm{d}, \mathrm{J}=6.8 \mathrm{~Hz})$ & $20.14(q)$ \\
\hline 20 & & $168.88(\mathrm{~s})$ \\
\hline 21 & $3.60(3 \mathrm{H}, \mathrm{s})$ & $54.63(q)$ \\
\hline \multirow[t]{2}{*}{22} & $5.67(1 \mathrm{H}, \mathrm{d}, J=1.7 \mathrm{~Hz})$ & $121.08(\mathrm{t})$ \\
\hline & $6.41(1 \mathrm{H}, \mathrm{d}, \mathrm{J}=1.0 \mathrm{~Hz})$ & \\
\hline 23 & $1.08(3 \mathrm{H}, \mathrm{d}, \mathrm{J}=6.6 \mathrm{~Hz})$ & $20.47(\mathrm{q})$ \\
\hline 24 & $0.89(3 \mathrm{H}, \mathrm{d}, \mathrm{J}=6.8 \mathrm{~Hz})$ & $23.60(\mathrm{q})$ \\
\hline
\end{tabular}


83.36), indicated the connectivity of the oxygen atom, and an absorption band of $1793 \mathrm{~cm}^{-1}$ for $\gamma$-lactone in the IR spectrum, thus the structure of chrolactomycin was determined as shown in Fig. 2.

In a NOESY experiment, NOEs between the methoxyl protons, $8-\mathrm{H}$ and $12-\mathrm{H}$, between $23-\mathrm{H}$ methyl protons and $8-\mathrm{H}$, and between $12-\mathrm{H}$ and $1-\mathrm{H}$ were observed. These connections show that the methoxyl group, 8-H, 12-H, 23-

Fig. 1. Partial structure of chrolactomycin.

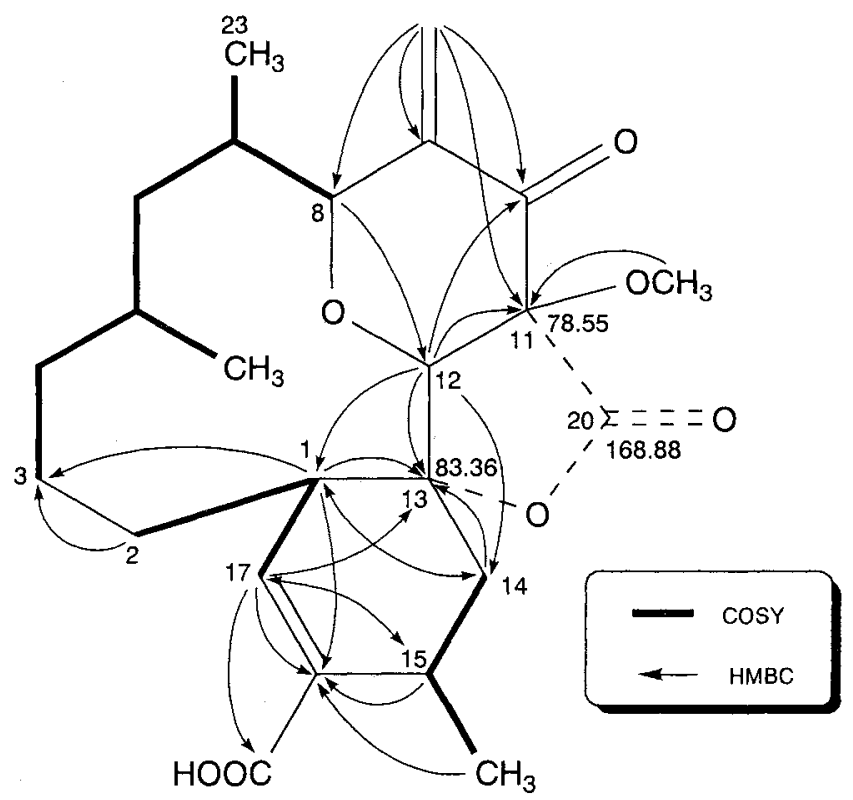

$\mathrm{H}$ methyl group and $1-\mathrm{H}$ were on the same plane. An analysis of other NOEs and coupling constants have indicated the structure of chrolactomycin as shown in Fig. 3 and the configuration is the same as that of okilactomycin $^{1,2)}$.

Fig. 3. Relative stereochemistry of chrolactomycin.

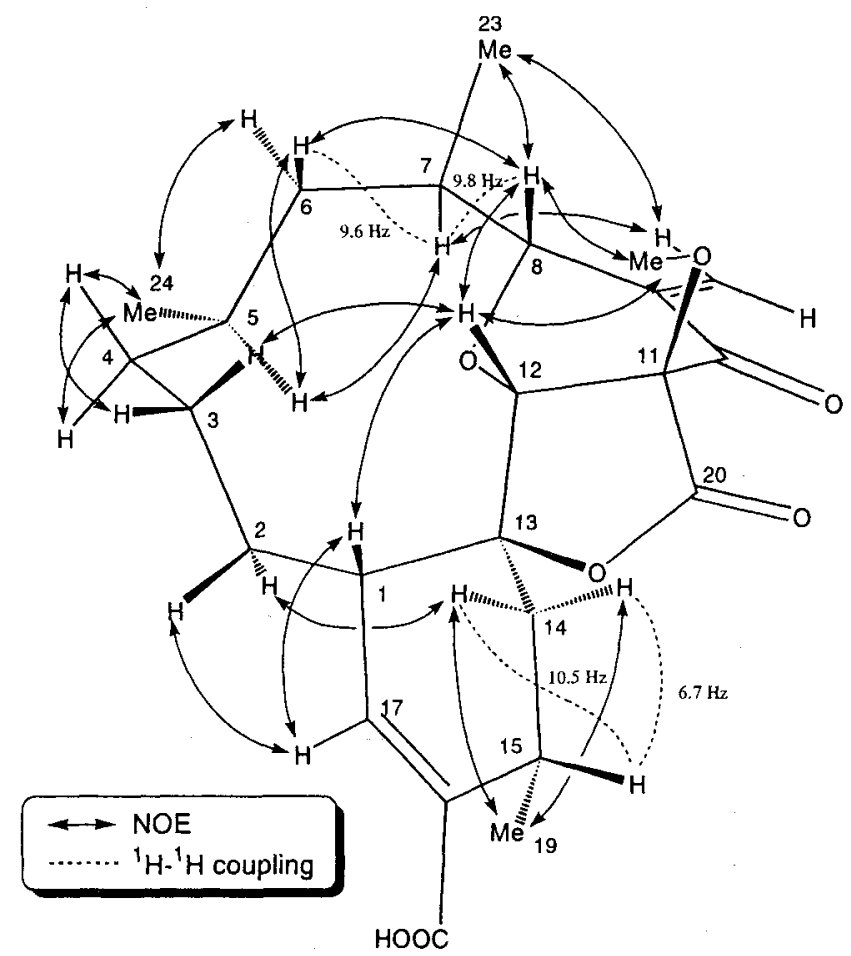

Fig. 2. Structure of chrolactomycin and okilactomycin.

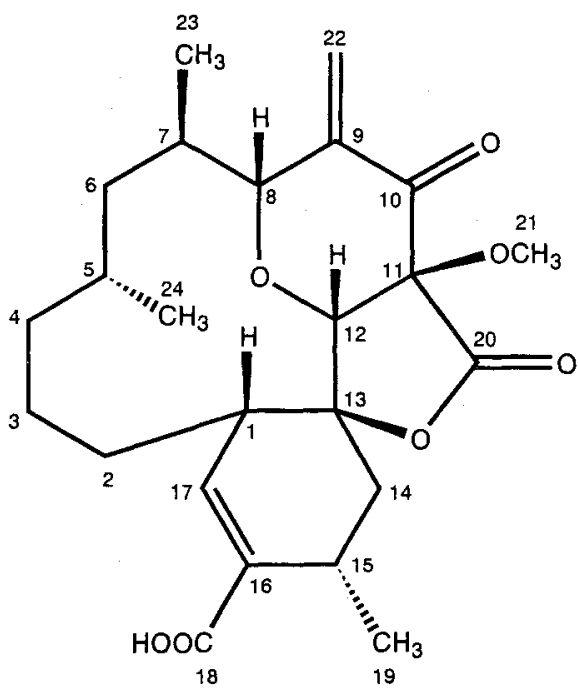

Chrolactomycin

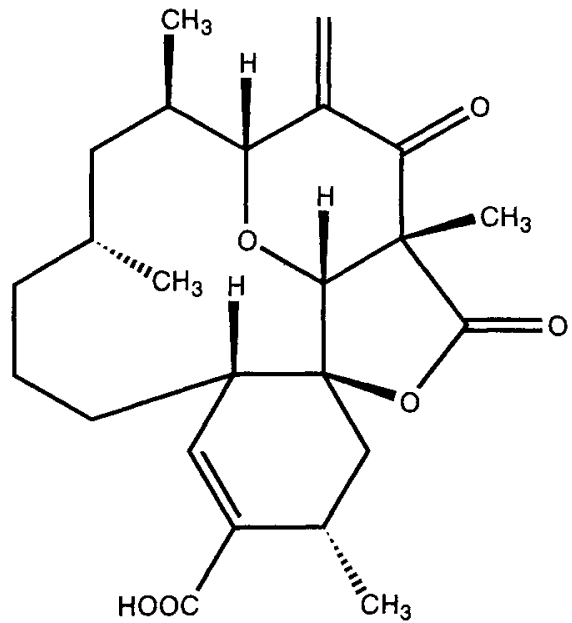

Okilactomycin 
Table 3. Antimicrobial activities of chrolactomycin.

\begin{tabular}{lc}
\hline Test microorganisms & MIC $(\mu \mathrm{g} / \mathrm{ml})$ \\
\hline Staphylococcus aureus subsp. aureus ATCC 6538 P & 5.2 \\
Bacillus subtilis No.10707 & 5.2 \\
Enterococcus hirae ATCC 10541 & 10.4 \\
Proteus vulgaris ATCC 6897 & $>83$ \\
Klebsiella pneumoniae subsp. pneumoniae ATCC 10031 & $>83$ \\
Escherichia coli ATCC 26 & $>83$ \\
Pseudomonas aeruginosa BMH No.1 & $>83$ \\
Shigella sonnei ATCC 9290 & $>83$ \\
Candida albicans ATCC 10231 & $>83$ \\
\hline
\end{tabular}

Table 4. Antiproliferative activities of chrolactomycin.

\begin{tabular}{lcl}
\hline \multirow{2}{*}{ Cell lines } & \multicolumn{2}{c}{$\mathrm{IC}_{50}(\mu \mathrm{M})$} \\
\cline { 2 - 3 } & Chrolactomycin & VP-16 \\
\hline $\mathrm{ACHN}$ & 1.2 & 0.33 \\
$\mathrm{~A} 431$ & 1.6 & 0.48 \\
$\mathrm{MCF} \cdot 7$ & 0.69 & 0.57 \\
$\mathrm{~T} 24$ & 0.45 & 1.2 \\
\hline
\end{tabular}

The antimicrobial activity of chrolactomycin is shown in Table 3. Chrolactomycin exhibited antimicrobial activity against Gram-positive bacteria, Staphylococcus aureus, Bacillus subtilis and Enterococcus hirae with the MIC values ranged from $5.2 \mu \mathrm{g} / \mathrm{ml}$ to $10.4 \mu \mathrm{g} / \mathrm{ml}$, but was inactive against Gram-negative bacteria and Candida albicans. According to the report of okilactomycin, comparison of the antimicrobial activities against Staphylococcus aureus supposes that chrolactomycin may be five times as potent as okilactomycin

The antiproliferative activity of chrolactomycin is shown in Table 4. Chrolactomycin exhibited antiproliferative activity against human tumor cell lines with $\mathrm{IC}_{50}$ values ranging from $0.45 \mu \mathrm{M}$ to $1.6 \mu \mathrm{M}$ after 72 hours exposure. The antiproliferative activity of chrolactomycin was comparable to that of VP-16 (etoposide). The fact that okilactomycin exhibited antitumor activity against Ehrlich ascites carcinoma ${ }^{1)}$ suggests that chrolactomycin may have antitumor activity in vivo. Detailed studies on the mechanism of action and antitumor activity of chrolactomycin are in progress.

\section{Acknowledgments}

The authors are grateful to Ms. MACHI KuSUNOKI for technical assistance.

\section{References}

1) Imai, H.; K. Suzuki, M. Morioka, Y. Numasaki, S. Kadota, K. Nagai, T. Sato, M. Iwanami \& T. Saito: Okilactomycin, a novel antibiotic produced by a Streptomyces species. I. Taxonomy, fermentation, isolation and characterization. J. Antibiotics 40: $1475 \sim 1482,1987$

2) Imai, H.; H. Kaniwa, T. TOKunaga, S. Funta, T. Furuya, H. Matsumoto \& M. Shimizu: Okilactomycin, a novel antibiotic produced by a Streptomyces species. II. Structure determination. J. Antibiotics 40: 1483 1489, 1987 